\title{
A
}

Acta HealthMedica

Acta HealthMedica (ISSN: 2414-6528)

http://www.ActaHealthMedica.com

Volume 3, Issue 3, July-September 2018, Pages: 268, DOI: http://dx.doi.org/10.19082/ah268

\section{CLEAVAGE OF TYPE IV COLLAGEN AS A KEY STEP IN THE MICROVASCULATURE DAMAGE INDUCED BY TWO HEMORRHAGIC METALLOPROTEINASES ISOLATED FROM CERASTES CERASTES VENOM}

\author{
Boukhalfa-Abib H., Tachoua W., Laraba-Djebari F. \\ hboukhalfabib@hotmail.com
}

USTHB, Faculty of Biological Sciences, Laboratory of Cellular and Molecular Biology, BP 32, El-Alia Bab Ezzouar, 16111, Algiers, Algeria

\section{TYPE OF ARTICLE: CONFERENCE ABSTRACT}

\begin{abstract}
Background: Snake venom of the Viperidae family induces hemorrhage, which is a typical consequence of envenomation. Microvasculature damage is the primary occurrence caused by Snake Venom Metalloproteinases (SVMPs). However, the precise mechanism by which SVMPs disrupt the microvasculature is as yet unclear. Cerastes cerastes venom was fractionated by different chromatographic steps and yielded two SVMPs; hemorrhagic CcMP-II and Cc HSM-III, causing a variety of local tissue damage.

Methods: In this study, we assessed the effect of these hemorrhagic metalloproteinases on extracellular matrix components. Collagenase activity was also tested using type IV collagen (from human placenta, Sigma). Samples of CcMP-II $\left(1,2,5,10,20\right.$ and $40 \mu \mathrm{g}$ in $\left.0.025 \mathrm{M} \mathrm{CaCl}_{2}\right)$ were incubated with type IV collagen in $0.05 \mathrm{M}$ Tris$\mathrm{HCl}, \mathrm{pH} 7.8$, for $24 \mathrm{~h}$ at $37^{\circ} \mathrm{C}$. Hydroxyproline released during an incubation of $24 \mathrm{~h}$ incubation was detected by ninhydrin reagent after boiling for $20 \mathrm{~min}$. N-propanol $50 \%$ was added after cooling. Collagenase activity was expressed as absorbance increase at $600 \mathrm{~nm}$ (USTHB, Faculty of Biological Sciences, BP 32, El-Alia Bab Ezzouar, 16111, Algiers, Algeria in 2016). The histopathological changes induced by CcMP-II and Cc HSM-III were also analyzed after injection into mouse dorsal skin by subcutaneously route. Tissue samples were collected $2 \mathrm{~h}$ after injection. Abundant erythrocytes were observed in the interstitium of muscle tissue injected with venom or purified molecules, whereas normal histological features were observed in control muscle injected with saline solution. Hematoxylin and eosin stain, magnification are 40x.

Results: The study showed that both hemorrhagic SVMPs (CcMP-II and Cc HSM-III) interfere with the homeostatic system by degrading fibrinogen. Indeed, CcMP-II and Cc HSM-III hydrolyzed preferentially the A $\alpha$ chain of fibrinogen in a time-dependent manner. Furthermore, the effect of CcMP-II and Cc HSM-III on extracellular matrix components, mainly type IV collagen, showed a complete degradation of this molecule $(4.37 \pm 0.15 \mathrm{~nm} / \mathrm{mg})$ within 30 minutes supporting by tissue damage of skin injected with CcMP-II and Cc HSMIII, revealing an extensive hemorrhage in the hypodermis and in skeletal muscle with a clear loosening of the bundles of collagen indicating a massive degradation of fibrillar collagen associated to an important leukocyte infiltration. The significance of the differences between the mean values of two experimental groups was assessed by the Students' $t$-test. Values of $p$ lower than 0.01 were considered significant

Conclusion: These results will contribute to better understanding the functional mechanisms of hemorrhagic effect, and may be useful in the development of therapeutic strategies for snakebite incidents.

KEYWORDS: Snake venom; Cerastes cerastes; Type IV collagen; Microvasculature damage
\end{abstract}

\footnotetext{
Abstracts of Third International Conference on Health Sciences and Medical Technologies, October 2018, Tlemcen, Algeria (ICHSMT-18)

(C) 2018 The Authors. This is an open access article under the terms of the Creative Commons Attribution-NonCommercialNoDerivs License, which permits use and distribution in any medium, provided the original work is properly cited, the use is non-commercial and no modifications or adaptations are made.
} 